\title{
Formation of Initiating Systems on the Basis of Cobalt Porphyrins and Benzoyl Peroxide in Chloroform and Methyl Methacrylate
}

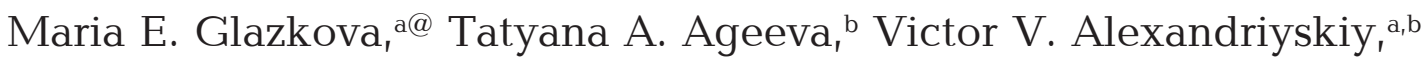 \\ and Oscar I. Koifman ${ }^{a, b}$ \\ ${ }^{a}$ Research Institute of Macroheterocyclic Compounds, Ivanovo State University of Chemistry and Technology, 153000 \\ Ivanovo, Russia \\ ' Institute of Solution Chemistry of Russian Academy of Sciences, 153045 Ivanovo, Russia \\ ${ }^{\circledR}$ Corresponding authorE-mail:mega@isuct.ru
}

\begin{abstract}
To understand the initiating mechanism of the radical polymerization of methyl methacrylate (MMA) in the presence of porphyrin complexes the interaction of Co porphyrins [5,10,15,20-tetraphenylporphyrin (CoTPP), 5,10,15,20-tetra(4methoxyphenyl)porphyrin (CoTP(MeO)P), 5,10,15,20-tetra(3-butoxyphenyl)porphyrin (CoTP(BuO)P)] with benzoyl peroxide in chloroform and methyl methacrylate was studied using a spectrophotometric method. Oxidation of these metalloporphyrins leads to the formation of isoporphyrins.
\end{abstract}

Keywords: Radical polymerization, initiating system, metalloporphyrin, benzoyl peroxide, isoporphyrin.

\section{Introduction}

It is known that metalloporphyrins are very effective catalysts of different processes. ${ }^{[1,2]}$ Cobalt complexes of porphyrins can be used as catalysts (initiators) of controlled ring-opening polymerization of various heterocyclic monomers ${ }^{[3]}$ and unsaturated monomers. ${ }^{[3-8]}$ There is a lot of works on the controlled radical polymerization in the presence of initiating system "metalloporphyrin - benzoyl peroxide", ${ }^{[8-10]}$ which leads to the synthesis of polymers with the specific molecular weight and chain-length distribution. But, to the best of our knowledge, there is no information about the interaction of metalloporphyrins with benzoyl peroxide during the polymerization process and the role of this type of interaction in the controlled radical polymerization is not so far revealed. Currently available data are insufficient for understanding of radical polymerization mechanism. The present work presents the first study of the interaction between Co porphyrins and benzoyl peroxide in chloroform and methyl methacrylate.

\section{Experimental}

Co complexes of 5,10,15,20-tetraphenylporphyrin (CoTPP), 5,10,15,20-tetra(4-methoxyphenyl)porphyrin $\quad$ (CoTP(MeO)P), 5,10,15,20-tetra(3-butoxyphenyl)porphyrin (CoTP(BuO)P) were prepared as described earlier. ${ }^{[11]}$ The model oxidation reaction of Co porphyrins was studied in chloroform $\left(\mathrm{CHCl}_{3}\right)$ and polymerization reaction in methyl methacrylate (MMA). These solvents ${ }^{[12]}$ and benzoyl peroxide (BP) were purified using known procedures. ${ }^{[13]}$

Electronic absorption spectra of CoTPP, CoTP(MeO)P, $\mathrm{CoTP}(\mathrm{BuO}) \mathrm{P}$ and benzoyl peroxide solutions in chloroform and methyl methacrylate were recorded on Lambda 20 PERKIN ELMER and Shumadzu «UV $2550 \mathrm{KC}$ » spectrophotometers. The kinetic measurements of the interaction between Co porphyrins and benzoyl peroxide in chloroform and methyl methacrylate were carried out by spectrophotometric method in hermetic quartz cuvettes.

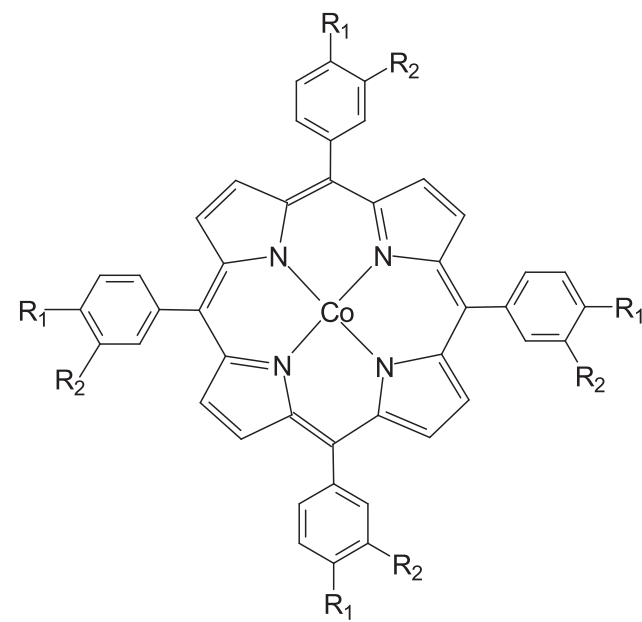

$$
\begin{gathered}
\mathbf{I}_{\mathbf{R}}=\mathbf{R}_{\mathbf{2}}=\mathbf{H} \\
\mathrm{Co}^{\mathrm{II}} \mathrm{TPP} \\
\text { II } \mathbf{R}_{\mathbf{1}}=\mathbf{O C} \mathbf{H}_{3}, \mathbf{R}_{2}=\mathbf{H} \\
\mathrm{Co}^{\mathrm{II}} \mathrm{TP}(\mathrm{MeO}) \mathrm{P} \\
\text { III } \mathbf{R}_{\mathbf{1}}=\mathbf{H}, \mathbf{R}_{2}=\mathbf{O C} \mathbf{C}_{4} \mathbf{H}_{9} \\
\mathrm{Co}^{\mathrm{II}} \mathrm{TP}(\mathrm{BuO}) \mathrm{P}
\end{gathered}
$$

\section{Results and Discussion}

In order to reveal some fundamental patterns of the formation of initiating systems on the basis of cobalt porphyrins and benzoyl peroxide in chloroform and methyl methacrylate we have studied the influences of the solvent nature and the porphyrin structure.

The mechanism of interaction of Co porphyrins and benzoyl peroxide may be presented by Scheme 1 .

The interaction of cobalt(II) porphyrins with benzoyl peroxide was investigated in $\mathrm{CHCl}_{3}$ and MMA at different ratio - at equimolar quantity $(1: 1)$, in excess $(1: 10)$ and deficit (5:1) of benzoyl peroxide. In all cases the characteristic 


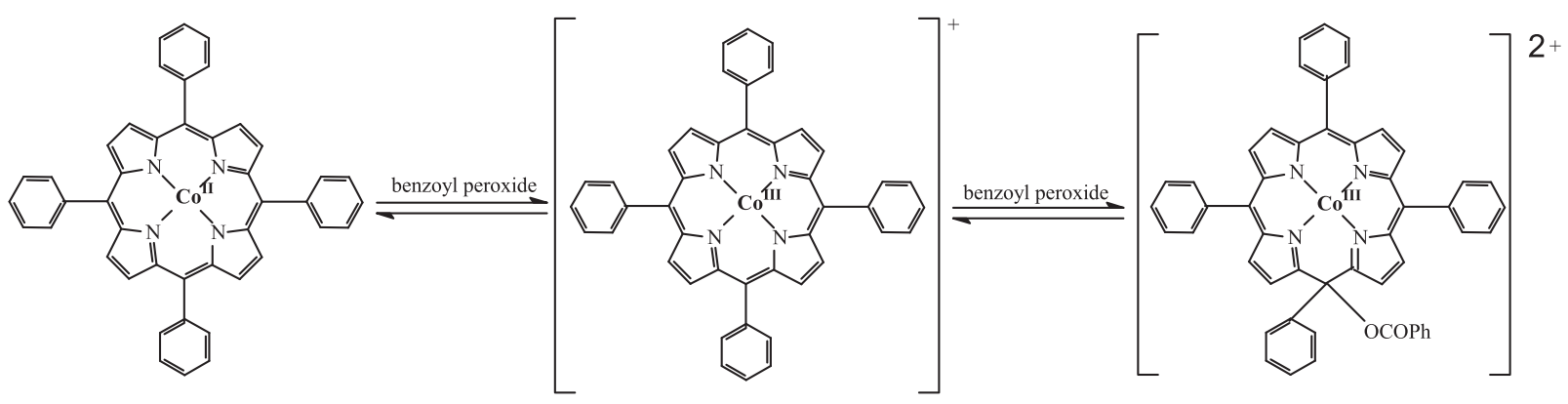

Scheme 1. The possible mechanism of interaction of Co porphyrins with benzoyl peroxide.

spectral changes were observed (Figure 1). Two groups of well-defined isosbestic points are indicative about the two consecutive steps: the first one is the oxidation of $\mathrm{Co}^{2+}$ to $\mathrm{Co}^{3+}$ (Figure 1a) ${ }^{[14,15]}$ and the second one is the formation of $\mathrm{Co}^{3+}$ isoporphyrin (Figure 1b). ${ }^{[16-18]}$ In the ${ }^{1} \mathrm{H}$ NMR spectrum of $\mathrm{Co}^{3+}$ isoporphyrin in $\mathrm{CDCl}_{3}$ the $\beta$-pyrrole protons appear at $6.36,6.62,7.04,7.24 \mathrm{ppm}$; the phenyl protons appear in the $7.4-7.8 \mathrm{ppm}$ region. ${ }^{[15]}$ The kinetic curves for the process of $\mathrm{CoTP}(\mathrm{BuO}) \mathrm{P}$ oxidation by benzoyl peroxide are presented in Figure 2. The character of the observed curves corresponds to the two consecutive reactions. ${ }^{[19]}$

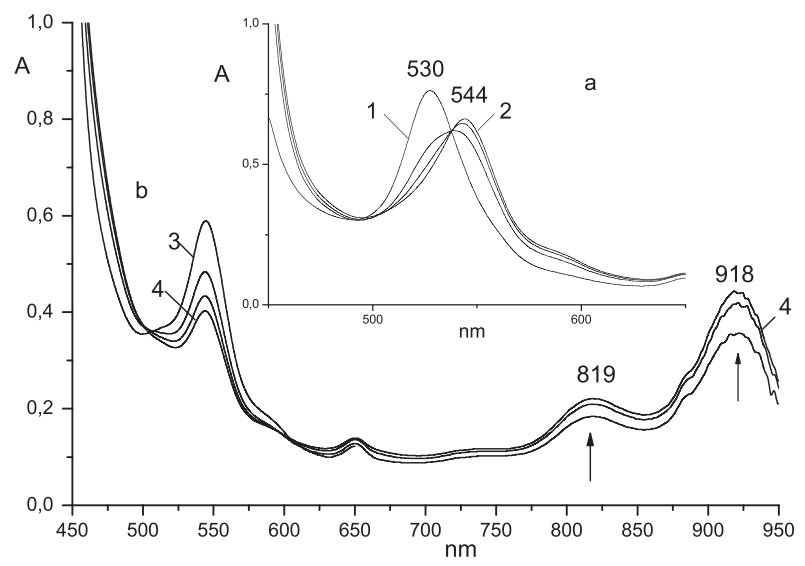

Figure 1. aChange of the electronic absorption spectra of $\operatorname{CoTP}(\mathrm{BuO}) \mathrm{P}\left(5 \cdot 10^{-5} \mathrm{~mol} / \mathrm{l}\right)$ in $\mathrm{CHCl}_{3}$ during oxidation by benzoyl peroxide $\left(5 \cdot 10^{-5} \mathrm{~mol} / \mathrm{l}\right)$ at $25^{\circ} \mathrm{C}: \mathbf{1}-\mathrm{Co}{ }^{\mathrm{II}} \mathrm{TP}(\mathrm{BuO}) \mathrm{P}$;

2- $\mathrm{Co}^{\mathrm{III}} \mathrm{TP}(\mathrm{BuO}) \mathrm{P}+\mathrm{BP}$ after $2 \mathrm{~min} ; \mathbf{3}, \mathbf{4}-\mathrm{Co}^{\mathrm{III}} \mathrm{TP}(\mathrm{BuO}) \mathrm{P}+\mathrm{BP}$ ( $\tau=2 \mathrm{~min} 30 \mathrm{sec}$ and $2 \mathrm{~h} 25 \mathrm{~min}$ ).

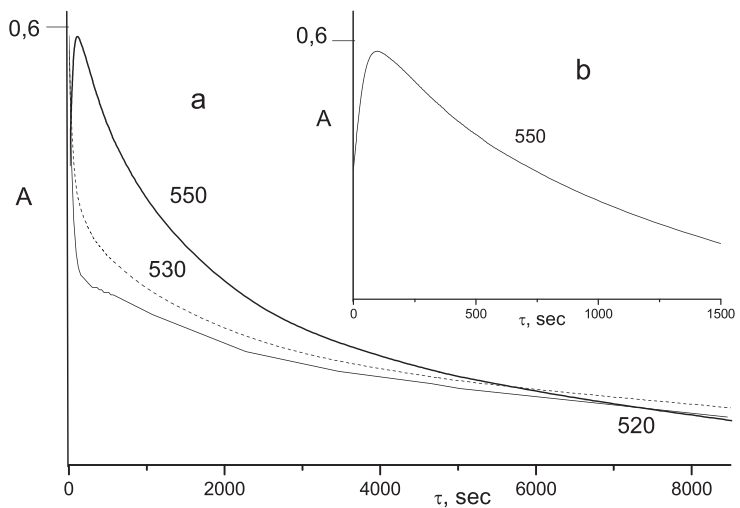

Figure 2. The kinetic curves for oxidation of $\mathrm{CoTP}(\mathrm{BuO}) \mathrm{P}\left(5 \cdot 10^{-5}\right.$ $\mathrm{mol} / \mathrm{l})$ by benzoyl peroxide $\left(5 \cdot 10^{-5} \mathrm{~mol} / \mathrm{l}\right)$ at $25^{\circ} \mathrm{C}(\mathrm{a})$. Insert (b) shows enlarged initial part of the kinetic curve.
The character of changes in the observed electronic absorption spectra is similar for all studied complexes (CoTPP, CoTP(MeO)P, CoTP(BuO)P). When $\mathrm{Co}^{\mathrm{III}}$ complex is formed at the first stage, the band in the visible region exhibits a weak bathochromic shift $(530 \mathrm{~nm} \rightarrow 547 \mathrm{~nm})$. This process is very fast. At the second stage, the intensity of the band in visible region decreases sharply, and the new longwave bands $(820 \mathrm{~nm}$ and $920 \mathrm{~nm})$ appear. These spectral changes correspond to the formation of isoporphyrin ${ }^{[16-18]}$ on the rate-limiting stage.

The interaction between of $\mathrm{Co}^{\text {II }}$ porphyrins with benzoyl peroxide in methyl methacrylate was studied for the first time. Experimental data show that the oxidation of $\mathrm{Co}^{\mathrm{II}}$ porphyrins in methyl methacrylate is slower than in chloroform. The character of electronic absorption spectra changes during the oxidation in MMA is similar to that in $\mathrm{CHCl}_{3}$ (Figure 4). The oxidation of CoTP(BuO)P in the excess of benzoyl peroxide during 3 hours at $45^{\circ} \mathrm{C}$ in the presence of oxygen (Figure 3) and after nitrogen blowing (Figure 4) leads to polymerization of MMA. It was noticed, that isoporphyrin is formed in both cases. The oxidation of CoTPP and CoTP(MeO)P by the excess of benzoyl peroxide in the presence of oxygen for 3 hours at $45^{\circ} \mathrm{C}$ does not lead to formation of polymer. The polymerization of MMA in the presence of CoTPP and CoTP(MeO)P was observed only after several days. So the most effective initiating system is 3-butoxy substituted complex $\mathrm{CoTP}(\mathrm{BuO}) \mathrm{P}$ in the presence of benzoyl peroxide.

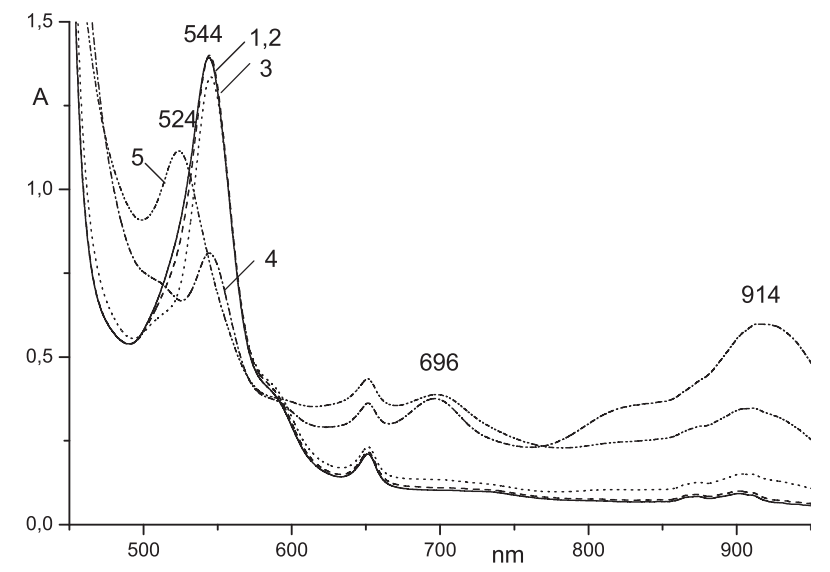

Figure 3. Changes of the electronic absorption spectra of $\mathrm{CoTP}(\mathrm{BuO}) \mathrm{P}\left(5 \cdot 10^{-5} \mathrm{~mol} / \mathrm{l}\right)$ during the oxidation by benzoyl peroxide $\left(2 \cdot 10^{-4} \mathrm{~mol} / \mathrm{l}\right)$ in methyl methacrylate: $\mathbf{1}-\mathrm{CoTP}(\mathrm{BuO}) \mathrm{P}$ in MMA at $25^{\circ} \mathrm{C} ; \mathbf{2}-\mathrm{CoTP}(\mathrm{BuO}) \mathrm{P}$ at $45^{\circ} \mathrm{C} ; \mathbf{3}-\mathrm{CoTP}(\mathrm{BuO}) \mathrm{P}+\mathrm{BP}$ at $45^{\circ} \mathrm{C}(\tau=0 \mathrm{~min}) ; 4-\mathrm{CoTP}(\mathrm{BuO}) \mathrm{P}+\mathrm{BP}$ in $\mathrm{MMA}(\tau=30 \mathrm{~min})$ at $45^{\circ} \mathrm{C}, \mathbf{5}-\mathrm{CoTP}(\mathrm{BuO}) \mathrm{P}+\mathrm{BP}$ in $\mathrm{MMA}(\tau=3 \mathrm{~h})$ at $45^{\circ} \mathrm{C}$. 


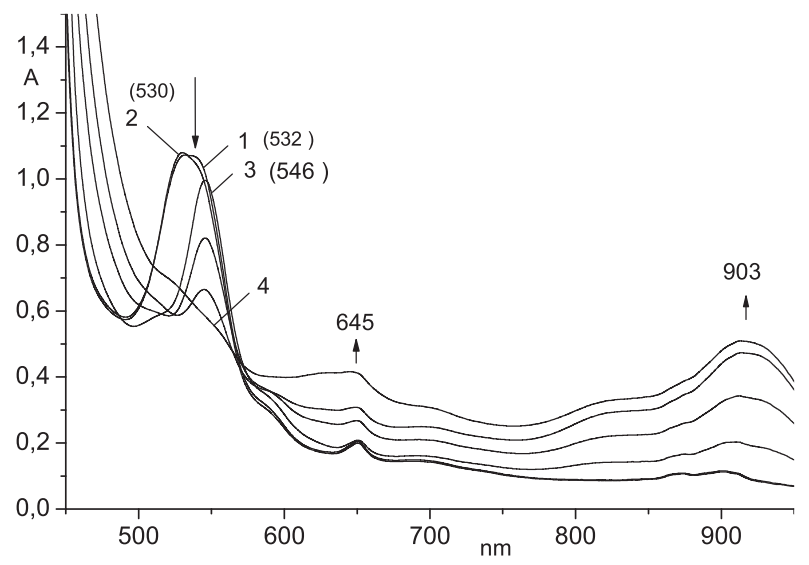

Figure 4. Changes of the electronic absorption spectra of CoTP(BuO)P $\left(5 \cdot 10^{-5} \mathrm{~mol} / \mathrm{l}\right)$ during its oxidation by benzoyl peroxide $\left(2 \cdot 10^{-4} \mathrm{~mol} / \mathrm{l}\right)$ in methyl methacrylate under $\mathrm{N}_{2}: \mathbf{1}-$ $\mathrm{CoTP}(\mathrm{BuO}) \mathrm{P}$ in MMA at $25^{\circ} \mathrm{C} ; \mathbf{2}-\mathrm{CoTP}(\mathrm{BuO}) \mathrm{P}$ at $45^{\circ} \mathrm{C} ; \mathbf{3}-$ $\mathrm{CoTP}(\mathrm{BuO}) \mathrm{P}+\mathrm{BP}$ at $45^{\circ} \mathrm{C}(\tau=0 \mathrm{~min}) ; 4-\mathrm{CoTP}(\mathrm{BuO}) \mathrm{P}+\mathrm{BP}$ in MMA at $45^{\circ} \mathrm{C}(\tau=3 \mathrm{~h})$.

\section{Kinetic Measurements}

The reaction of oxidation in an excess of benzoyl peroxide can be considered to be of the pseudo first order. ${ }^{[20]}$ The rate constants of cobalt isoporphyrin formation were calculated using Equations (1) and (2):

$$
\begin{aligned}
& k_{o b s}=\frac{2.3}{\tau} \lg \frac{C_{0}}{C} \\
& k_{v}=\frac{k_{o b s}}{C_{B P}}
\end{aligned}
$$

$k_{\text {obs }}$ - observed constant, $\tau$ - time of the reaction, $C_{\mathrm{o}}$ and $C$ - initial concentration of cobalt(III) porphyrin and its concentration during the process, $C_{\mathrm{BP}}-$ concentration of benzoyl peroxide $(\tau=0 \mathrm{~min})$.

The dependence of $\lg \left(C_{0} / C\right)$ vs. $\tau$ for oxidation of Co porphyrin $\left(5 \cdot 10^{-5} \mathrm{~mol} / \mathrm{l}\right)$ by benzoyl peroxide $\left(5 \cdot 10^{-4} \mathrm{~mol} / \mathrm{l}\right)$ in $\mathrm{CHCl}_{3}$ at $25{ }^{\circ} \mathrm{C}$ is linear (Figure 5) which is typical for the first order reactions.

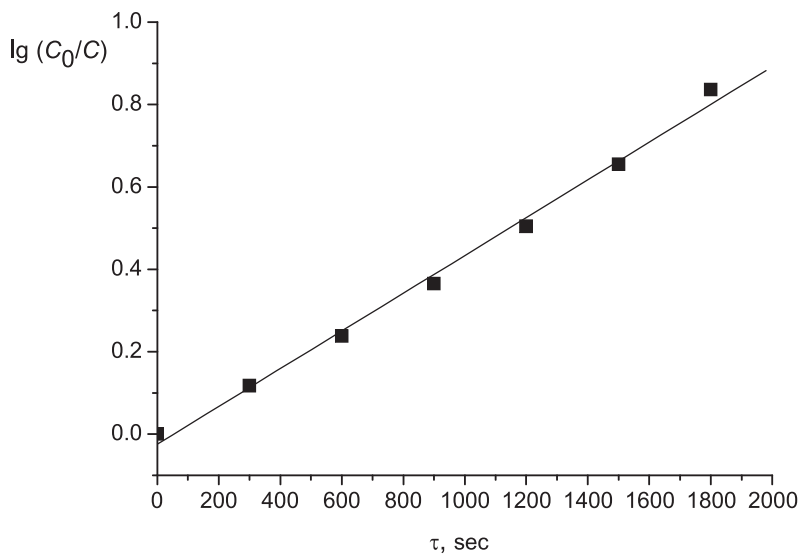

Figure 5. Dependence $\lg \left(C_{0} / C\right) v s . \tau$ for CoTPP $\left(5 \cdot 10^{-5} \mathrm{~mol} / \mathrm{l}\right)+\mathrm{BP}$ $\left(5 \cdot 10^{-4} \mathrm{~mole} / \mathrm{l}\right)$ in $\mathrm{CHCl}_{3}$ at $25{ }^{\circ} \mathrm{C}$.
Table 2. The constants of cobalt isoporphyrins formation in $\mathrm{CHCl}_{3}$ $\left(C_{\mathrm{CoP}}: C_{\mathrm{BP}}=1: 10\right)$.

\begin{tabular}{ccc}
\hline Cobalt porphyrin & $k_{\mathrm{obs}} \cdot 10^{4}, \mathrm{sec}^{-1}$ & $k_{\mathrm{v}}, \mathrm{mol}^{-1} \cdot \mathrm{sec}^{-1}$ \\
\hline CoTPP & $10.4 \pm 0.5$ & $2.0 \pm 0.1$ \\
CoTP(MeO)P & $18.3 \pm 1.1$ & $3.7 \pm 0.1$ \\
CoTP $(\mathrm{BuO}) \mathrm{P}$ & $8.2 \pm 0.5$ & $1.6 \pm 0.08$ \\
\hline
\end{tabular}

\section{Conclusions}

The oxidation of cobalt complexes of 5,10,15,20-tetraphenylporphyrin, 5,10,15,20-tetra(4methoxyphenyl)porphyrin,5,10,15,20-tetra(3-butoxyphenyl) porphyrin by benzoyl peroxide in chloroform and methyl methacrylate was studied using spectrophotometric method. These processes consist of two stages: the first is oxidation of $\mathrm{Co}^{\mathrm{II}}$ to $\mathrm{Co}^{\mathrm{III}}$, and the second is the formation of $\mathrm{Co}^{\mathrm{III}}$ isoporphyrin. Change of chloroform by methyl methacrylate leads only to the slower reaction process. The most effective initiating system consists of 5,10,15,20-tetra(3-butoxyphenyl) porphyrin and benzoyl peroxide.

Acknowledgements. This work was supported by Russian Foundation for Basic Research (grants RFBR № 09-03-00927 and № 10-03-01000). We also thank Prof. Semeikin A.S. (Ivanovo State University of Chemistry and Technology) for the synthesis of porphyrin samples.

\section{References}

1. Berezin B.D., Enikilopyan N.S. Metalloporfiriny [Metalloporphyrins]. Moskva: Nauka, 1988. 160 p. (in Russ.).

2. Ageeva T.A., Koifman O.I. Porfirinpolimery [Porphyrinpolymers]. Moskva: Izd. fiz. mat. liter., 2006. 194 p. (in Russ.).

3. Aida T., Inoue S . Metalloporphyrins as Catalysts for Precision Macromolecular Synthesis. In: The Porphyrin Handbook, Vol. 6. (K.M. Kadish, K.M. Smith, R. Guilard, Eds.) New York: Academic Press, 2000, p. 133-156.

4. Li Y., Wayland B. B. Chem. Commun. 2003, 1594-1595.

5. Aida T., Inoue S. Acc. Chem. Res. 1996, 29, 39-48.

6. Hosokawa Y., Kuroki M., Aida T., Inoue S. Macromolecules 1991, 24, 824-829.

7. Kuroki M., Aida T., Inoue S. J. Am. Chem. Soc. 1987, 109, 4737-4738.

8. Monakov Yu.B., Koifman O.I., Islamova R.M., Nasretdinova R.N. Porfiriny i ikh metallokompleksy v radikal'noy polimerizatsii vinilovykh isomerov [Porphyrins and their Metallocomplexes in Radical Polymerization of Vinyl Monomers]. In: Uspekhi Khimii Porfirinov [Advances in Porphyrin Chemistry], Vol. 5. SPb.: NII Khimii SPbGU, 2007. p. 293- 314. (in Russ.).

9. Monakov Yu.B., Islamova R.M., Koifman O.I. Macroheterocycles 2009, 2, 237-242..

10. Islamova R.M. Izv. Vyssh. Uchebn. Zaved., Khim. Khim. Tekhnol. 2010, 53 (2), 16-29 (in Russ.).

11. Adler A.D., Kongo F.R., Kampas F., Kim J. J. Inorg. Nucl. Chem. 1970, 32, 2443-2445.

12. Gordon A.J., Ford R.A. The Chemist's Companion New York, London, Sydney, Toronto: Wiley, 1972.

13. Toroptseva A.M., Belogorodskaya K.V., Bondarenko V.M Laboratornyi praktikum po khimii i tekhnologii vysokomoleculyarnykh soedinenii [Practicum on Chemistry and Technology 
M.E. Glazkova et al.

of Macromolecular Compounds] Leningrad: Khimiya, 1972. 416 p. (in Russ.).

14. Reddy D., Reddy N.S., Chandrashekar T.K., Hans van Willigen. J. Chem. Soc. Dalton Trans. 1991, 2097-2101.

15. Kurmaz S.V., Perepelitcina E.O. Russ. Chem. Bull. 2006, 55, 835-844.

16. Lee W.A., Bruice T.C. Inorg. Chem. 1986, 25, 131-135.

17. Dolphin D. Annals New York Academy of Sciences 1973, 177-201.
18. Kurtikyan T.S., Stepanyan T.G. Russ. Chem. Bull. 1998, 47, $695-698$.

19. Panchenkov G.M., Lebedev V.P. Khimicheskaya Kinetika $i$ Kataliz [Chemical Kinetics and Catalysis] Moskva: Khimia, 1985. 592 p. (in Russ.).

20. Schmid R., Sapunov V.N. Non-Formal Kinetics: In Search of Chemical Reaction Pathways. Weinheim, Verlag Chemie, 1982. $199 \mathrm{p}$

Received 30.12 .10 Accepted 24.02.11 